\title{
Credit Card Disclosures, Solicitations, and Privacy Notices: Survey Results of Consumer Knowledge and Behavior
}

Thomas A. Durkin, of the Board's Division of Research and Statistics, prepared this article. Christine $N$. Jones provided research assistance.

The mandatory dissemination of certain information by financial institutions is a key aspect of consumer protection law. It offers two significant advantages for consumer protection in the financial area over the alternative of direct government intervention into product pricing and content. First, information disclosure is compatible with competition, a significant market force already at work to protect consumers by keeping price rises in check. Because of competition, institutions already have incentives to make their products known, to reveal favorable pricing and product features, and to treat consumers fairly by keeping them generally informed about what they want and need to know. When a financial institution employs these strategies, it generates a good business reputation that will produce referrals and repeat customers. Actions that firms use to accomplish these goals include advertising their prices and supplying clients and potential customers with useful information about product prices and features.

The requirements for disclosures assist in the dissemination of financial information by standardizing concepts and terminology, such as the finance charge and annual percentage rate under the Truth in Lending Act and the annual percentage yield under the Truth in Savings Act. Such standardization advances consumers' knowledge about pricing and features of the financial products and institutions and lowers consumers' transactions costs by making shopping easier. The standard format of required disclosures helps highlight the performance of the best institutions and exposes the inadequacies of the poorer ones. Well-informed shoppers help keep markets competitive, which benefits buyers of products and services by minimizing the spread between producers' production costs and market price. ${ }^{1}$

The second advantage of information disclosure over direct intervention through mandating specific product pricing or features is that the government need not know, or presume to know, the product feature preferences of all consumers. With effective disclosures, consumers can decide what their preferences are in the tradeoff between price and product features; the success of the disclosure approach to consumer protection does not depend on consumers' preferences being the same. Disclosure requirements may also be less costly for financial institutions to implement and for the government to enforce than consumer protection approaches that limit product features.

\footnotetext{
1. Researchers have published a significant body of theoretical and empirical work on the benefits of information and disclosure. Among the important articles are George J. Stigler (1961), "The Economics of Information," Journal of Political Economy, vol. 69 (June), pp. 21325; Phillip Nelson (1970), "Information and Consumer Behavior," Journal of Political Economy, vol. 78 (March-April), pp. 311-20; George Akerlof (1970), "The Market for Lemons: Qualitative Uncertainty and the Market Mechanism," Quarterly Journal of Economics, vol. 84 (August), pp. 488-500; Michael A. Spence (1973), "Job Market Signaling," Quarterly Journal of Economics, vol. 87 (August), pp. 355-74; Michael Rothschild (1973), "Models of Market Organization with Imperfect Information: A Survey," Journal of Political Economy, vol. 81 (November), pp. 1283-1308; Howard Beales, Richard Craswell, and Steven C. Salop (1981), "The Efficient Regulation of Consumer Information," Journal of Law and Economics, vol. 24 (December), pp. 491-539; Joseph E. Stiglitz (1985), "Information and Economic Analysis," The Economic Journal, vol. 95, Supplement: Conference Papers, 1985 (March), pp. 21-41; and Pauline M. Ippolito (1988), "The Economics of Information in Consumer Markets: What Do We Know? What Do We Need to Know?" in E. Scott Maynes, ed., The Frontiers of Research in the Consumer Interest (Columbia, MO: American Council on Consumer Interests), pp. 23563. Important government reports include Federal Trade Commission Staff (1979), Consumer Information Remedies Policy Session (Washington: Federal Trade Commission); and Board of Governors of the Federal Reserve System (1987), Annual Percentage Rate Demonstration Project (Washington: Board of Governors of the Federal Reserve System).
} 


\section{TRUTH IN LENDING ACT AND DISCLOSURES}

The Congress in May 1968 passed the Truth in Lending Act, the first in a series of federal consumer protection laws that addressed primarily financial disclosures. ${ }^{2}$ This act was designed to protect consumers in credit transactions by requiring clear disclosure of key terms of the credit arrangement and all credit costs. The law was implemented in 1969 by the Federal Reserve Board through Regulation Z, which prescribes uniform methods for computing the cost of credit, for disclosing credit terms, and for resolving errors on certain types of credit accounts. In 1976, the Congress amended the act to cover consumer leasing, and the Federal Reserve implemented Regulation M, which covers the rules of all consumer leasing transactions and includes disclosure of leasing terms.

Credit cards are the most widely used method of generating consumer credit. The credit card industry estimates that more than 1 billion credit cards were in the hands of customers in the United States at the end of 2004. ${ }^{3}$ When they use their cards, consumers receive monthly account statements that contain disclosures about credit use, costs, and obligations for payments. Elsewhere on the monthly statements, consumers receive disclosures concerning such items as grace periods, membership fees, minimum finance charges, and procedures for questioning and resolving billing errors. In addition, consumers frequently receive mailed solicitations for new accounts, and these mailings carry disclosures. In recent years, consumers have also begun receiving privacy notices from their financial institutions, and these notices contain disclosures outlining the institutions' privacy policies and information on how customers can "opt out" of certain kinds of information sharing among institutions.

The content, format, and number of disclosures have evolved and changed since passage of the Truth in Lending Act. ${ }^{4}$ As these mandatory disclosures have

2. Other statutes that focus on financial disclosure are the Real Estate Settlement Procedures Act (1974), the Consumer Leasing Act (1976), and the Truth in Savings Act (1991). The main intent of these laws is to protect consumers by the mandatory disclosure of certain information. Other consumer protection laws also contain important requirements for disclosures, though they are not primarily disclosure statutes; examples include the Fair Credit Reporting Act (1971), the Equal Credit Opportunity Act (1974), and the Electronic Fund Transfer Act (1978).

3. Thomson Financial Media (2005), Card Industry Directory, 17th ed. (New York: Thomson Financial Media), p. 16.

4. Various recent legislative and regulatory initiatives concerning credit cards have continued to underscore interest in what consumers know about their accounts, how they use disclosure information, what they think is important in the disclosures, and what information they taken their place in the financial marketplace and as consumer financial services have expanded and evolved, researchers and other observers have been interested in whether consumers use the disclosures they receive and, if so, how they use them. One way to examine consumer knowledge and use of the disclosures is through surveys. For this reason, the Federal Reserve Board has conducted and analyzed targeted, nationally representative consumer surveys in this area since a before-and-after study of the original implementation of the Truth in Lending Act. ${ }^{5}$ Nationally representative surveys provide information about consumers' impressions and experiences to supplement institutional knowledge from public comments generated through the regulatory process. Targeted consumer surveys help reduce the need to rely unduly on opinions of interested parties or anecdotal

want to receive. In the legislative area, the Fair and Accurate Credit Transactions (FACT) Act of 2003, which amended the Fair Credit Reporting Act of 1971, provided for additional disclosures to consumers about how they could more easily take their names off solicitation lists for new or additional credit cards, a removal process sometimes also referred to as opting out. This act also required the Federal Reserve Board to undertake a study of credit card solicitations, which the Board completed in December 2004. In April 2005, the Bankruptcy Abuse Prevention and Consumer Protection Act mandated new provisions for the Truth in Lending Act concerning open-end consumer credit, and it required further Board studies of consumers and their credit.

On the regulatory front, in December 2004 the Federal Reserve Board began formal review and updating of Regulation $\mathrm{Z}$, the rule that implements Truth in Lending. The first step in the review process was an Advance Notice of Proposed Rulemaking (ANPR), which asked for comments on a lengthy list of questions about open-end consumer credit. The full review process will take some time and will likely raise many additional questions about how well consumers understand credit products and how they use them, including credit cards. In October 2005, the Federal Reserve reopened the ANPR comment period, asking for public comment on issues raised by Truth in Lending Act amendments in the bankruptcy reform legislation that year. Interagency initiatives to revise privacy notification rules for financial accounts, including credit card accounts, are also under way. In each of these efforts, what consumers know and want to know have been important questions.

5. Robert P. Shay and Milton P. Schober (1973), Consumer Awareness of Annual Percentage Rates of Charge in Consumer Installment Credit: Before and After Truth in Lending Became Effective, vol. 1.: Technical Studies of the National Commission on Consumer Finance (Washington: Government Printing Office). For later survey results, refer to Thomas A. Durkin and Gregory E. Elliehausen (1978), The 1977 Consumer Credit Survey (Washington: Board of Governors of the Federal Reserve System); Anthony W. Cyrnak and Glenn B. Canner (1986), "Consumer Experiences with Credit Insurance: Some New Evidence," Federal Reserve Bank of San Francisco Economic Review (Summer), pp. 5-20; Gregory E. Elliehausen and Barbara R. Lowrey (1997), The Cost of Implementing Consumer Financial Regulations: An Analysis of Experience with the Truth in Savings Act, Staff Study 170 (Washington: Board of Governors of the Federal Reserve System); Thomas A. Durkin (2000), "Credit Cards: Use and Consumer Attitudes, 1970-2000," Federal Reserve Bulletin, vol. 86 (September), pp. 623-34; and Thomas A. Durkin (2002), "Consumers and Credit Disclosures: Credit Cards and Credit Insurance," Federal Reserve Bulletin, vol. 88 (April), pp. 201-13. 
reports for assessments of consumers' disclosure use and their preferences.

In 2004 and 2005, several surveys were undertaken to assess consumers' knowledge of, familiarity with, and attitudes about credit card disclosures, credit card solicitations, and privacy notices received from their financial institutions. ${ }^{6}$ The targeted surveys supplemented the comprehensive Surveys of Consumer Finances, which are undertaken every three years and which provide general benchmarks and growth trends for consumer assets, debts, and use of financial services. ${ }^{7}$ In each case, the survey goal was to assess the frequency with which consumers examine or consult disclosures and their attitudes toward the disclosures received. If consumers look at the disclosures frequently and are favorably inclined toward their usefulness, then the benefits of informed credit use and of enhanced competition in the market for financial products can follow.

\section{CREDIT CARD PERIODIC STATEMENTS AND DISCLOSURES}

In January 2005, the Federal Reserve Board sponsored a survey about the importance to consumers of various required disclosures for their credit card accounts, consumers' use of the disclosure information provided, and their new accounts and payment of fees. Slightly more than 73 percent of respondents reported holding one or more general-purpose credit cards with a revolving credit feature. The cards are sometimes called bank-type credit cards because they used to be issued only by banks; examples are cards like Discover, MasterCard, and Visa, which are usable at a wide variety of outlets and which can

6. The surveys cited in this article were undertaken for the Federal Reserve Board by the Survey Research Center of the University of Michigan. The center conducted 500 interviews on credit card solicitations and privacy notices in May 2004 and 494 interviews on credit card periodic statements in January 2005.

7. The 1995, 1998, 2001, and 2004 Surveys of Consumer Finances are discussed, respectively, in Arthur B. Kennickell, Martha StarrMcCluer, and Annika E. Sunden (1997), "Family Finances in the U.S.: Recent Evidence from the Survey of Consumer Finances," Federal Reserve Bulletin, vol. 83 (January), pp. 1-24; Arthur B. Kennickell, Martha Starr-McCluer, and Brian J. Surette (2000), "Recent Changes in U.S. Family Finances: Results from the 1998 Survey of Consumer Finances," Federal Reserve Bulletin, vol. 86 (January), pp. 1-29; Ana M. Aizcorbe, Arthur B. Kennickell, and Kevin B. Moore (2003), "Recent Changes in U.S. Family Finances: Evidence from the 1998 and 2001 Survey of Consumer Finances," Federal Reserve Bulletin, vol. 89 (January), pp. 1-32; and Brian K. Bucks, Arthur B. Kennickell, and Kevin B. Moore (2006), "Recent Changes in U.S. Family Finances: Results from the 2001 and 2004 Survey of Consumer Finances," Federal Reserve Bulletin, vol. 92, pp. A1-A38, www.federalreserve.gov/pubs/bulletin/default.htm.
1. Examination frequency of selected disclosure information among holders of bank-type credit cards, 2005

Percent of cardholders

\begin{tabular}{|c|c|c|}
\hline \multirow[b]{2}{*}{ Item } & \multicolumn{2}{|c|}{ Disclosure information } \\
\hline & $\begin{array}{c}\text { Annual } \\
\text { percentage } \\
\text { rate }\end{array}$ & $\begin{array}{c}\text { Descriptive } \\
\text { material }\end{array}$ \\
\hline Frequent examination & & \\
\hline Every month $\ldots \ldots \ldots$ & 46.6 & 12.1 \\
\hline Every other month $\ldots \ldots \ldots$ & 5.6 & 6.2 \\
\hline Four to five times per year & 11.3 & 15.5 \\
\hline Subtotal ................ & 61.5 & 33.8 \\
\hline Infrequent examination & & \\
\hline $\begin{array}{l}\text { Less often than four to five times } \\
\text { per year } \ldots \ldots \ldots \ldots \ldots \ldots \ldots\end{array}$ & 29.6 & 57.7 \\
\hline Never (volunteered) ............... & 8.9 & 8.6 \\
\hline Subtotal .......... & 38.5 & 66.3 \\
\hline Total . & 100.0 & 100.0 \\
\hline
\end{tabular}

SOURCE: Surveys of Consumers, January 2005

generate revolving credit if the user chooses to pay less than the full statement balance.

One line of questioning directly asked consumers with this type of card how often they examined the pricing and other disclosures they received monthly as part of the periodic statements from the cardissuing bank. If the disclosures are examined frequently, especially the pricing disclosures, then the Truth in Lending Act can have a favorable effect on "the informed use of credit," as the Congress intended. ${ }^{8}$

Consumers gave the full range of possible answers to the question on how often they examine the annual percentage rates (APRs). The majority of cardholders (62 percent) said they looked at the APRs on their card accounts at least four times or more per year, timing characterized for discussion here as "frequently" (table 1). More than 40 percent said they looked at the APRs monthly. In contrast, the majority (66 percent) said they looked at the descriptive material, the information often found on the back of statements, fewer than four to five times a year, timing characterized here as "infrequently."

Not surprisingly, the frequency of APR examination correlates directly with the use of cards as credit

8. The Congress articulated its central goal for Truth in Lending in section 102 of the act: "The Congress finds that economic stabilization would be enhanced and the competition among the various financial institutions and other firms engaged in the extension of consumer credit would be strengthened by the informed use of credit. The informed use of credit results from an awareness of the cost thereof by consumers. It is the purpose of this title to assure a meaningful disclosure of credit terms so that the consumer will be able to compare more readily the various credit terms available to him and avoid the uninformed use of credit." 
2. Examination frequency of annual percentage rate (APR) and of descriptive material by cardholder group, 2005 Percent of group

\begin{tabular}{|c|c|}
\hline Cardholder group & Response \\
\hline \multirow{2}{*}{\multicolumn{2}{|c|}{ Groups of consumers more likely to examine APR frequently }} \\
\hline & \\
\hline Have three or more general-purpose revolving cards $\ldots \ldots$ & 66.5 \\
\hline 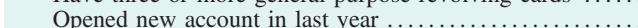 & 67.4 \\
\hline \multicolumn{2}{|l|}{ Balance } \\
\hline Balance after last payment positive but less than $\$ 1,500$ & 68.4 \\
\hline Balance after last payment at least $\$ 1,500$ but less than & 740 \\
\hline 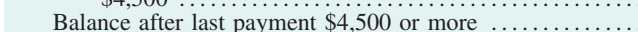 & $\begin{array}{l}74.0 \\
79.7\end{array}$ \\
\hline \multicolumn{2}{|l|}{ Revolving balance } \\
\hline Pay full balance hardly ever & 79.2 \\
\hline Pay full balance sometimes. & 81.6 \\
\hline \multicolumn{2}{|l|}{ Groups of consumers less likely to examine APR frequently } \\
\hline Account status & \\
\hline Have one or two general-purpose revolving cards & 57.4 \\
\hline Did not open new account in last year ........... & 59.8 \\
\hline \multicolumn{2}{|l|}{ Balance } \\
\hline No balance outstanding after last payment & 40.8 \\
\hline Revolving balance & \\
\hline Pay full balance almost always & 46.7 \\
\hline \multicolumn{2}{|l|}{$\begin{array}{l}\text { Groups of consumers more likely to examine } \\
\text { descriptive material frequently }\end{array}$} \\
\hline Account status & \\
\hline Opened new account in last year & 36.7 \\
\hline \multicolumn{2}{|l|}{ Balance } \\
\hline Balance after last payment positive but less than $\$ 1,500$ & 38.8 \\
\hline Balance after last payment at least $\$ 1,500$ but less than & \\
\hline $\begin{array}{c}\$ 4,500 \ldots \ldots \ldots \ldots \ldots \ldots \ldots \ldots \ldots \ldots \\
\text { Balance after last payment } \$ 4,500 \text { or more } \ldots \ldots\end{array}$ & $\begin{array}{l}37.0 \\
39.7\end{array}$ \\
\hline \multicolumn{2}{|l|}{ Revolving balance } \\
\hline Pay full balance hardly ever & 39.9 \\
\hline Pay full balance sometimes . & 45.7 \\
\hline \multicolumn{2}{|l|}{$\begin{array}{l}\text { Groups of consumers less likely to examine } \\
\text { descriptive material frequently }\end{array}$} \\
\hline \multicolumn{2}{|l|}{ Account status } \\
\hline Did not open new account in last year & 32.9 \\
\hline \multicolumn{2}{|l|}{$\begin{array}{l}\text { Balance } \\
\text { Bact open new account in last year }\end{array}$} \\
\hline No balance outstanding after last payment & 23.5 \\
\hline \multicolumn{2}{|l|}{ Revolving balance } \\
\hline Pay full balance almost always & 26.8 \\
\hline
\end{tabular}

Source: Surveys of Consumers, January 2005.

generators rather than as convenient transaction devices. The survey found that a credit card holder was likely to examine the rate more frequently as credit use increased. Specifically, about 41 percent of cardholders reporting no balance outstanding said they examined the APR frequently; by comparison, about 80 percent of those with an outstanding balance of $\$ 4,500$ or more examined the APR frequently (table 2 ). In general, those with smaller outstanding balances at the time of the interview and those who said they normally pay their balances in full were less likely to examine the APR frequently. These findings seem entirely reasonable because the cost of using credit cards as credit devices would be more important to those using this kind of credit regularly, and so they are more likely to examine APRs. Credit cost is not as likely to be important to those who mostly use their cards as transaction devices.

As noted, the percentage of those who examine the descriptive material frequently is much lower than the percentage of those who examine the APR frequently. The descriptive information tends to be denser than the pricing disclosures, and arguably it is of less interest to many consumers because it is more general and appears more legalistic. Also, much of it pertains to more-limited circumstances, such as balance computation formulas and service calls for errors or for further information, which are less likely than price comparison to be the objective of consumer shopping. The proportion of cardholders who reported frequent examination of this information did not vary as much according to account usage as APR examination, but the pattern was generally the same. Those who used their credit cards as credit-generating devices examined this material more frequently than those who used their cards as transactions devices. Almost twofifths of the respondents with balances reported examining this information frequently, but only about one-quarter of those with no balance after their last payment did so.

To ascertain what specific information on their monthly statement consumers consider important, they were asked two open-ended questions: What information did they consider important enough to look at each month? What information is most important? The interviewers recorded up to two replies for each question.

Respondents gave various answers to both questions; however, their replies could be grouped into four categories: cost measures, correctness of credit card statement, measures of personal finances, and miscellaneous (table 3). Seventeen percent replied that cost measures were most important to them, especially interest rates, compared with 29 percent who replied that aspects of statement correctness were most important to them. More than 60 percent replied that the data on the periodic statement related to aspects of their overall personal financial condition were the most important information, especially the balance owed.

As with examination frequency of the APR on the periodic statement, which category of information the respondents considered most important is correlated with whether they use their cards as credit-generating devices or mostly for transactions. Of those with a credit card balance of more than $\$ 1,500$, more than one-quarter said that cost measures were the most important information for them; of those with no balance outstanding, less than 10 percent said cost measures were most important. In contrast, among those who replied that correctness measures were most important, the percentage was higher among those with no balance outstanding than the percentage of those with revolving balances. Overall, however, personal financial measures, especially balance owed, 
3. Importance of selected disclosure information on periodic statements among holders of bank-type credit cards, and distribution of responses by cardholder group, 2005

Percent

\begin{tabular}{|c|c|c|}
\hline Category of disclosure information & Most important & Important \\
\hline \multicolumn{3}{|l|}{ Costs } \\
\hline Any mention of costs & 17.0 & 40.2 \\
\hline Interest rate ......... & 13.5 & 30.1 \\
\hline Specific fees or fees & 3.2 & 9.4 \\
\hline Finance charges .... & 1.1 & 5.0 \\
\hline \multicolumn{3}{|l|}{$\begin{array}{l}\text { Any mention of costs within } \\
\text { cardholder groups }\end{array}$} \\
\hline Pay full balance almost always & 10.1 & 30.5 \\
\hline Pay full balance sometimes.... & 21.0 & 57.9 \\
\hline Pay full balance hardly ever & 25.1 & 49.5 \\
\hline No balance outstanding $\ldots \ldots \ldots \ldots . . .$. & 7.2 & 24.0 \\
\hline Balance positive but less than $\$ 1,500$ & 15.5 & 41.2 \\
\hline Balance at least $\$ 1,500$ but less & & \\
\hline than $\$ 4,500 \ldots \ldots \ldots \ldots$ & 25.0 & 49.5 \\
\hline Balance $\$ 4,500$ or more & 27.2 & 56.9 \\
\hline \multicolumn{3}{|l|}{ Correctness of billing statement } \\
\hline Any mention of correctness ........ & 29.3 & 51.4 \\
\hline $\begin{array}{l}\text { Purchases, transactions, charges, } \\
\text { returns are correct }\end{array}$ & 28.2 & 46.2 \\
\hline Previous payment received …....... & $\begin{array}{r}20.2 \\
1.8\end{array}$ & $\begin{array}{r}40.2 \\
9.1\end{array}$ \\
\hline Account number, name, and so forth & & \\
\hline \multirow{2}{*}{\multicolumn{3}{|c|}{ Any mention of correctness within }} \\
\hline & & \\
\hline $\begin{array}{l}\text { Pay full balance almost always } \\
\text { Pay full balance sometimes .... }\end{array}$ & $\begin{array}{l}35.3 \\
31.0\end{array}$ & $\begin{array}{l}53.9 \\
56.3\end{array}$ \\
\hline Pay full balance hardly ever. & 19.8 & 47.5 \\
\hline No balance outstanding $\ldots \ldots \ldots \ldots . .$. & 40.5 & 60.8 \\
\hline Balance positive but less than $\$ 1,500$ & 19.7 & 40.5 \\
\hline Balance at least $\$ 1,500$ but less & & \\
\hline than $\$ 4,500 \ldots \ldots \ldots \ldots$ & 18.3 & 48.1 \\
\hline Balance $\$ 4,500$ or more & 26.6 & 50.3 \\
\hline \multicolumn{3}{|l|}{ Personal finances } \\
\hline Any mention of personal finances & 61.0 & 83.3 \\
\hline Balance owed...$\ldots \ldots \ldots \ldots$ & 53.5 & 75.2 \\
\hline Due date $\ldots \ldots \ldots \ldots \ldots \ldots \ldots$ & 5.0 & 19.5 \\
\hline Itemization; where money was spent & 2.5 & 11.6 \\
\hline Minimum payment...$\ldots \ldots \ldots \ldots$ & 1.1 & 3.4 \\
\hline Credit limit; available credit & .4 & 2.1 \\
\hline Keeping track of debt ....... & $*$ & .3 \\
\hline \multicolumn{3}{|l|}{$\begin{array}{l}\text { Any mention of personal finances } \\
\text { within cardholder groups }\end{array}$} \\
\hline Pay full balance almost always & 61.6 & 84.7 \\
\hline Pay full balance sometimes .... & 53.7 & 73.2 \\
\hline Pay full balance hardly ever & 63.6 & 85.7 \\
\hline No balance outstanding $. . . \ldots \ldots \ldots . . . .$. & 58.5 & 82.2 \\
\hline Balance positive but less than $\$ 1,500$ & 70.4 & 86.3 \\
\hline Balance at least $\$ 1,500$ but less & & \\
\hline than $\$ 4,500 \ldots \ldots \ldots \ldots$ & 66.4 & 85.1 \\
\hline Balance $\$ 4,500$ or more $\ldots$ & 55.2 & 83.4 \\
\hline \multicolumn{3}{|l|}{ Miscellaneous } \\
\hline Any mention of miscellaneous $\ldots \ldots$ & .9 & 4.6 \\
\hline Details of and changes in policies & .9 & 2.4 \\
\hline Rebates, incentives, rewards ..... & $*$ & 1.9 \\
\hline Billing date ............... & * & .3 \\
\hline Grace period . & * & $*$ \\
\hline
\end{tabular}

NotE: Components do not sum to totals because some respondents gave more than one response.

* Percentage too small to be measured.

SOURCE: Surveys of Consumers, January 2005.

were mentioned most often as most important, and the percentage did not vary much with patterns of credit use (third panel of table 3 ).

The same patterns are visible among those variables that consumers report as being important enough that they look at them monthly, even if they are not the most important information. Notably, 57 percent of those with relatively large outstanding balances on their credit cards reported that they reviewed cost
4. Response to question of whether annual percentage rate (APR) or finance charge affected card use decisions among holders of bank-type credit cards, and distribution of responses by cardholder group, 2005 Percent

\begin{tabular}{|c|c|c|c|}
\hline Group category & APR & $\begin{array}{c}\text { Finance } \\
\text { charge }\end{array}$ & Either \\
\hline All respondents $\ldots \ldots \ldots$. & 27.3 & 24.5 & 39.2 \\
\hline Within cardholder groups & & & \\
\hline Pay full balance almost always & 16.8 & 21.1 & 29.5 \\
\hline Pay full balance sometimes .... & 50.0 & 29.5 & 57.4 \\
\hline Pay full balance hardly ever & 36.4 & 29.5 & 50.0 \\
\hline No balance outstanding $\ldots \ldots \ldots \ldots$. & 15.7 & 15.2 & 22.5 \\
\hline Balance positive but less than $\$ 1,500$ & 30.3 & 28.9 & 52.8 \\
\hline Balance at least $\$ 1,500$ but less & & & \\
\hline Balance $\$ 4,500$ or more $\ldots \ldots \ldots$ & $\begin{array}{l}33.6 \\
41.7\end{array}$ & $\begin{array}{l}33.2 \\
31.7\end{array}$ & $\begin{array}{l}51.4 \\
51.0\end{array}$ \\
\hline
\end{tabular}

SOURCE: Surveys of Consumers, January 2005.

measures at least monthly, whereas 24 percent of those with no balance outstanding after their last payment reviewed them monthly (first panel of table 3). Again, measures of personal finances are mentioned most often as being consulted monthly, especially total balance owed.

The survey further explored the use of disclosures about APRs and finance charges through direct questions. Toward the end of the interview, consumers were asked specifically whether APRs and finance charge disclosures had affected credit decisions. Not surprisingly, the pattern of responses was similar to that discussed earlier. Those with frequently revolving balances and those with relatively large outstanding balances were much more likely to respond that APRs and finance charges had affected their card use behavior (table 4). When the responses of both groups are combined, about 40 percent of respondents said that either the APR or the finance charge had affected their card use decisions.

The proportions differ sharply within cardholder subgroups, however; the proportion of those with revolving balances who stated that the cost information on their monthly statements had affected their card use decisions was much higher than the proportion of convenience users who said so. More than half of those reporting that they paid the full balance sometimes or hardly ever and those who reported a balance outstanding after making their last payment indicated that the APR, finance charge, or either had affected their card use decisions. When asked how this information had affected their decisions, the most common responses were that it made them decide to pay off their balances more quickly, encouraged them to stop using a particular account or to use the account with the lowest rate, or encouraged them to limit card use altogether (data not in table). When asked the rate on the general-purpose card they used most often, only about 4 percent of those with 
revolving balances said they did not know the rate, whereas the others with revolving balances responded with rates within reasonable ranges. These results support the view that Truth in Lending has been important in providing useful information to users of credit cards as credit-generating devices.

The interviewer asked all respondents with generalpurpose credit cards whether the distinction made on credit card account statements between a finance charge and other kinds of charges and fees made a difference to them. All respondents to this question, whether answering yes or no, were then asked why they responded the way they did.

Interestingly, 77 percent indicated that the distinction mattered. At first glance, it might seem that this distinction likely would not matter because a fee is a fee regardless what it is called, but respondents indicated that the distinction does matter to them. One possibility is that consumers like to feel comfortable that someone else is keeping an eye on credit card companies, a phenomenon noted in an earlier Bulletin article. ${ }^{9}$ The government provides that monitorship of credit card companies through the requirements of the Truth in Lending Act, and consumers can use the disclosures to examine fees and how they are classified under the act.

This interest in monitoring fees is apparent in the answers to the question about why they responded in the way they did. For those who felt the distinction was important, the most common reasons given were that they wanted to know specifically what they were paying for and that they wanted to avoid fees (data not in table). The specific fees most commonly mentioned were annual fees and late fees, neither of which is actually classified as a finance charge under Truth in Lending, and avoidance of "unexpected fees," which was not further specified by type. Absence in the open-ended response of a differentiation between fees by classification suggests that consumers actually do not have much interest in the legal distinctions despite their expression to the contrary. What is apparent, however, is that they want to know the amounts of fees so that they can fully understand what is behind the payments requested on their periodic bills.

Among those who said that the distinction between finance charges and other sorts of fees was not important, the two most common reasons were that they paid off their bills in full, so such distinctions did not matter to them, or that all charges are the same. Thus, the responses of both groups suggest that

9. Durkin, "Consumers and Credit Disclosures," p. 208. hair-splitting legal distinctions among categories of fees are really not so important to consumers as long as the charges are clear and understandable.

The interviewers did not ask further questions about fees like annual fees, late fees, and over-limit fees that are not finance charges under Truth in Lending. But they did ask about experience with fees for cash advances and convenience checks that are considered finance charges under the regulation. About 15 percent of those with bank-type credit cards reported that they had paid either or both of these fees in the past year (data not in table).

The number of bank-type cardholders who reported paying such finance charges is fairly small (15 percent), so a detailed analysis of the financial condition of the consumers within this group is precluded. But it is worth noting that most of those reporting that they had paid these finance charges also said they knew about the charges before the transaction. When asked, most indicated they had learned about the charges from the disclosures given to them.

In contrast, relatively few of those reporting they had paid these finance charges recalled seeing the effect of the charges on the APR on their statements that month. Truth in Lending requires that all finance charges be factored into an "effective" APR that is to be included on each periodic (monthly) statement. In a month in which a finance charge arises from a source other than application of the normal periodic rate to the balance (for example, finance charges for cash advances and for convenience checks), the charge must be factored into the disclosed APR that month as the effective APR (sometimes referred to as the "historical" APR).

Less than one-quarter of the 15 percent of cardholders reporting these charges for cash advances or convenience checks (about 3.5 percent of bank-type cardholders overall) said they noticed any change in the APR in the month of the fee. Because every cardholder paying one of these fees would find a higher APR on the statement that month, the low response does not strongly support the efficacy and usefulness of this disclosure for the majority of cardholders. For some, the change may have been so small in the month in question that it could have gone unnoticed, or the respondents may not have noticed changes that occurred infrequently. Some may have noticed the change at the time it happened but may have forgotten by the time of the interview.

Finally, those who responded affirmatively to a question about opening a new account in the past year were asked a few additional questions about accountopening statement disclosures. This group was asked 
only a few more questions because of the likelihood that the proportion with new accounts would be relatively small; in a specialized interview, subdividing the group in many interesting ways would not be possible because of its small size. Overall, about 22 percent of respondents with general-purpose credit cards said that they had opened a new credit card account within "the past year or so" (data not in table).

Each respondent with a new account was asked about the use and storage of the account-opening disclosure information. Most indicated that they had read the information at least somewhat carefully and had kept it for later use if needed (data not in table). Some of the respondents may have been thinking of the solicitation disclosures that are delineated in a tabular format rather than the actual account-opening disclosures, but the questioning did not make this differentiation. About three-quarters of those with new accounts said that the disclosures were useful, mostly because they provided information about interest rates or reference information to catch mistakes and make comparisons. Among the limited number of respondents who said that the information was not useful, most said that there was too much information or that it was too confusing or legalistic.

In sum, the response to questions on the use of periodic statements shows that many holders of banktype credit cards look at the disclosures fairly often. The frequency with which they examine rates and fees is correlated with whether or not they have a revolving balance. Those paying their balances in full each month also tend to look at the statements frequently, but they do so to ensure accuracy of the statements and to assess their personal financial condition. The distinction between finance charges and other fees does not seem especially important despite protests to the contrary. Most of those with revolving balances on their general-purpose credit cards seem broadly aware of APRs, but the small number of responses about the effective APR suggests that infrequent changes do not receive much notice. However, the overall findings do indicate that the goal of the informed use of credit by consumers is being addressed, as the Congress intended.

\section{CREDIT CARD SOLICITATIONS AND DISCLOSURES}

The general findings that reported usefulness of required disclosures on periodic statements is correlated with measures of credit card usage are broadly consistent with the results of another specialized survey of credit card users undertaken in May 2004.
This survey focused especially on credit card solicitations rather than on periodic statements. In recent years, prescreened mail solicitations, which employ credit experience information from the files of creditreporting agencies, have become an important source of new accounts for card issuers; more than 6 billion solicitations were mailed in 2005. ${ }^{10}$ Although many of the surveyed consumers do not review carefully the mailings they receive, the requirement that the mailings contain pricing information means that a large volume of information on credit card pricing makes its way regularly into consumers' mailboxes. The specialized survey focused on consumers' experience with the receipt of these mailings. Some results from this survey were included in a report to the Congress required in 2004 by the Fair and Accurate Credit Transactions Act of 2003.11

The 2004 survey found that 77 percent of respondents had one or more credit cards at that time and that 72 percent had one or more general-purpose credit cards with a revolving feature (bank-type credit cards). Of the cardholder group, more than 96 percent had received prescreened mail solicitations for one or more additional credit cards in the previous six months, and 81 percent of noncardholders had received one or more solicitations. Most respondents receiving solicitations had received more than one per month (table 5). About 50 percent of cardholders and 30 percent of noncardholders had received six or more prescreened solicitations a month over the previous half year. Only a small proportion of either group had received only one prescreened solicitation or none per month during this period.

The survey asked the respondents with credit cards who had received prescreened solicitations for more information about their experiences with the mailings. ${ }^{12}$ One question concerned attitudes toward the information in the mailings and asked if it was helpful. About 9 percent indicated they did not know, so they probably did not pay much attention to the information (first panel of table 6). The rest of the respondents were almost evenly divided on whether

10. Information Policy Institute (2003), The Fair Credit Reporting Act: Access, Efficiency \& Opportunity: The Economic Importance of Fair Credit Reauthorization, table 13, p. 57; and Synovate, Mail Monitor (2006), "Mail Monitor Reports Six Billion Card Offers Mailed in U.S. During 2005," press release, June, http:// core.synovate.com

11. Board of Governors of the Federal Reserve System (2004), Report to the Congress on Further Restrictions on Unsolicited Written Offers of Credit and Insurance (Washington: Board of Governors of the Federal Reserve System, December).

12. The survey did not ask those without credit cards many follow-up questions about their experiences with solicitations because the small sample size of this group would not permit further classification breakdown of their experiences. 
5. Cardholders and noncardholders: Credit card solicitations, awareness of opt-out law, and behavior response, 2004

Percent

\begin{tabular}{|c|c|c|}
\hline Consumers receiving solicitations & Cardholders & Noncardholders \\
\hline Total & 77.0 & 23.0 \\
\hline $\begin{array}{l}\text { Received solicitations for additional } \\
\text { cards in previous six months } .\end{array}$ & 96.1 & 80.8 \\
\hline $\begin{array}{l}\text { Approximate number of solicitations } \\
\text { received monthly }\end{array}$ & & \\
\hline One or fewer $\ldots \ldots \ldots \ldots \ldots \ldots$ & 11.8 & 18.9 \\
\hline Two to five .. & 36.7 & 50.6 \\
\hline $\begin{array}{l}\text { Six or more } \\
\text { Total }\end{array}$ & $\begin{array}{r}51.5 \\
\mathbf{1 0 0 . 0}\end{array}$ & $\begin{array}{r}30.5 \\
\mathbf{1 0 0 . 0}\end{array}$ \\
\hline Aware of opt-out law & 20.8 & 16.9 \\
\hline Response to awareness & & \\
\hline Opted out $\ldots \ldots \ldots \ldots$ & 20.3 & 33.3 \\
\hline Thought about opting out ... & 38.2 & 13.9 \\
\hline Did not consider opting out & 41.6 & 52.8 \\
\hline Total ................... & 100.0 & 100.0 \\
\hline
\end{tabular}

NoTE: Components may not sum to totals because of rounding. Source: Surveys of Consumers, May 2004.

or not the information received was helpful: About 40 percent said it was helpful, and slightly less than 50 percent said it was not. Within the two negativeresponse subgroups, a much higher proportion took the more extreme position that the information was very unhelpful, probably an indicator of frustration with receiving so much junk mail. Regardless, the finding that a significant portion of consumers appeared to be generally familiar with the kind of information in the prescreened solicitations-whether they stated it was helpful or not-is consistent with the view that the prevalence of prescreened solicitations is useful in disseminating pricing information and encouraging competitive conditions in markets for credit cards generally, even if only a small minority of recipients actually responds to a given prescreened solicitation program.

The respondents answering that the information was helpful were asked what specific information was helpful. About two-thirds mentioned interest rates or APRs (second panel of table 6). Some noted that they found particular information on other rates helpfulfor example, introductory rates or standard rates. About one-third mentioned specific information about various fees, such as annual fees, balance-transfer fees, and late fees. Again, the findings suggest that many consumers seem to know what the prescreened solicitations contain, which is important for price competition to work, even if they do not respond to, or even focus carefully on, the contents of any given piece of mail that they receive from card issuers. ${ }^{13}$

13. A follow-up question asked both those who said the information was helpful and those who said it was not how it could be made more helpful. Respondents gave a wide variety of answers, but those already
6. Credit card solicitations: Opinions on helpfulness of disclosure information, and distribution of responses by cardholder group, 2004

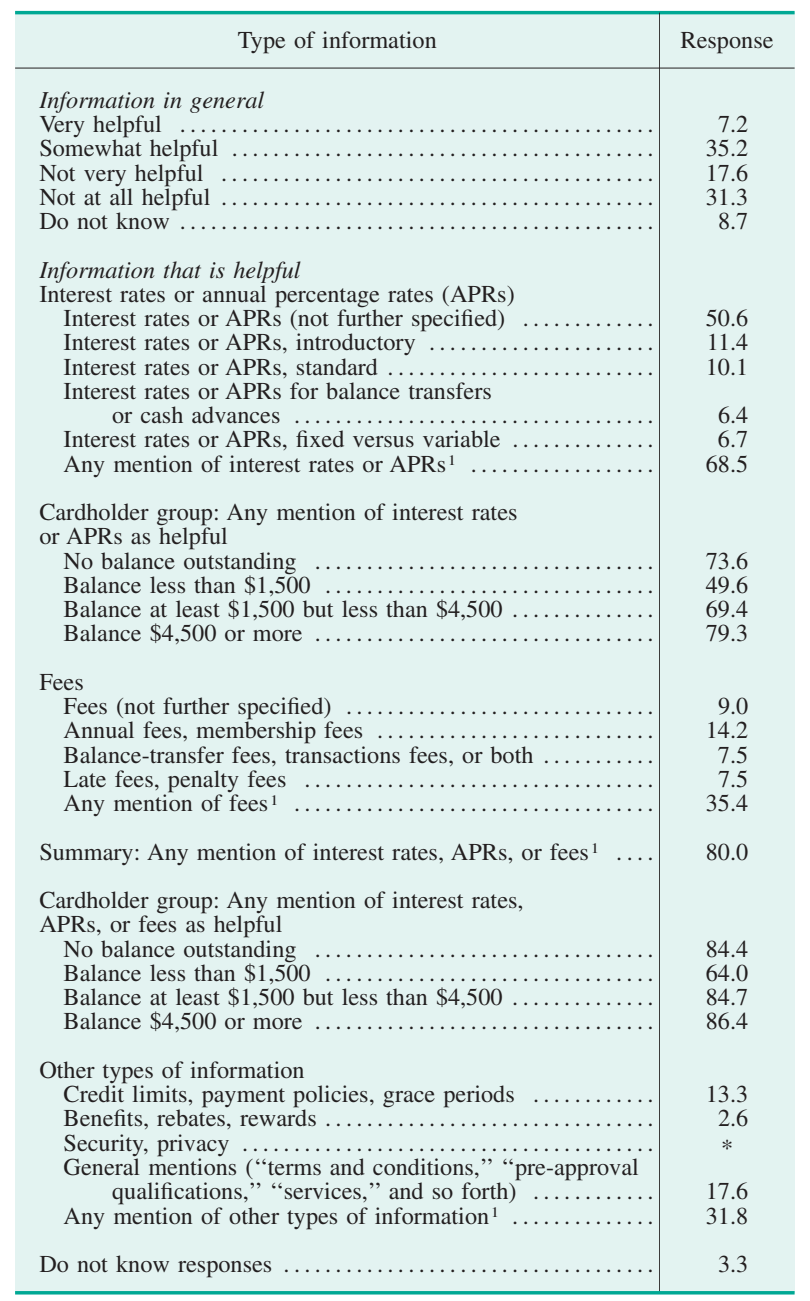

1. The responses to these categories do not sum to totals because respondents could give up to two replies.

* Less than 0.5 percent.

SourCE: Surveys of Consumers, May 2004.

Another question asked consumers what they actually do most often with the mailings they receive. Responses indicate that the mailings are not solely or always considered junk mail, even if they are so regarded in many instances. Slightly more than half of respondents (55 percent) said that they throw them away, but the others said they at least open and look at them-but not especially carefully (table 7). Members of the group who said they usually opened the prescreened solicitations were asked a follow-up

favorably inclined toward the information often suggested aspects of format and clarity (data not in table). Those unfavorably inclined often indicated either that they did know how the information could be improved or said that fewer mailings should be sent. The possibility is that the latter were not looking for any more credit cards and were frustrated with the frequency of junk mail. 
7. Disposition of credit card solicitations, and distribution of behavior response by cardholder group, 2004 Percent

\begin{tabular}{|c|c|}
\hline Behavior & Response \\
\hline Respondents receiving solicitations & \\
\hline Open and glance at them ........... & 34.2 \\
\hline Open and look more carefully & 10.0 \\
\hline Subtotal: Open and look at & 44.6 \\
\hline $\begin{array}{l}\text { Cardholder group: Those who open and } \\
\text { look at solicitations }\end{array}$ & \\
\hline With one general-purpose credit card ... & 41.7 \\
\hline With two general-purpose credit cards ........... & 40.7 \\
\hline With three or more general-purpose credit cards & 48.7 \\
\hline With no balance outstanding $\ldots \ldots \ldots \ldots \ldots \ldots$ & 40.9 \\
\hline Balance less than $\$ 1,500 \ldots \ldots \ldots \ldots \ldots$ & 42.4 \\
\hline Balance at least $\$ 1,500$ but less than $\$ 4,500$ & 47.5 \\
\hline Balance $\$ 4,500$ or more $\ldots \ldots \ldots \ldots \ldots \ldots \ldots$ & 52.9 \\
\hline Receive 1 solicitation per month ........ & 72.2 \\
\hline Receive 2 to 5 solicitations per month ..... & 46.8 \\
\hline Receive 6 or more solicitations per month & 37.1 \\
\hline Throw them away ....... & 55.4 \\
\hline Total & 100.0 \\
\hline
\end{tabular}

SOURCE: Surveys of Consumers, May 2004.

question about whether they looked for any particular information, and if so, what information. About twothirds gave various answers that mostly focused on pricing information (data not in table). The remaining one-third said that they looked for no particular information. While many consider the mailings junk and tend to rapidly dispose of them, not all consumers throw them away without consulting them. Many are clearly aware of the contents of the mailings they receive; in other words, they have direct access to pricing and product information at a time when they can decide about opening a new credit card account. ${ }^{14}$

As with attention to different aspects of periodic statements, behavior with respect to solicitations varied by credit use. Those with more cards and those with larger outstanding balances were more likely to examine the mailings than those with fewer cards and those with smaller balances. This finding suggests that active credit users are more likely to be looking for cards that have more-favorable credit terms than those of their current card accounts. Also noteworthy is that those who indicated receiving solicitations infrequently were also more likely to open and at least glance at the documents. This finding may indicate that some of them may have been poor credit risks in the past and for this reason receive infrequent solicitations, so the ones they do receive are of special interest to them.

The survey also asked respondents about removing their names from prescreened solicitation lists.

14. Responses to a further question in the survey revealed that about 9 percent of those with credit cards and receiving solicitations in the past six months had responded to a solicitation from some card issuer during that time period (data not in table).
About 20 percent of both cardholders and noncardholders answered that they had heard of a federal law in this area. In turn, about 20 percent of cardholders and 33 percent of noncardholders who said they knew of the federal law had placed their names on an opt-out list (lower panel of table 5). This response means that about 4 percent to 6 percent of respondents had placed their names on the opt-out list. ${ }^{15}$ Because the survey found that only about 20 percent of consumers were aware of their right under federal law to opt out from prescreened solicitations, increased awareness may lead more consumers to do so. For consumers aware of the law, a larger proportion of those with credit cards than those without (38 percent versus 14 percent) said that they had thought about placing their names on the opt-out list but had not yet done so.

Consumers in the group aware of the federal law were also asked how they had heard of it. Most mentioned their information was from the media, especially television, newspapers, and magazines (data not in table). Some consumers also mentioned family, acquaintances, and other sources. Less than one-tenth of those with credit cards and aware of the law indicated that they learned of the right to opt out from the prescreened mail solicitation. With passage of additional time since the May 2004 survey on solicitations and opting out, one possibility is that a higher proportion of recipients would be aware of opt-out rights today than at the time of the survey.

Finally, a factor in an empirical finding from earlier surveys may explain why the proportion of consumers opting out was not higher in 2004 than it was, given that the number of those who knew of their opt-out rights was considerably higher than the number of those who actually opted out. In particular, earlier surveys found that consumers seem to maintain strong feelings about what other consumers know or do not know and how they behave. This phenomenon, seen in earlier survey results, is characterized as the "other guy effect," whereby consumers indicate that they are better informed and likely to be more responsible than unknown "others." 16 Because many feel that their own private finances are under better control than those of consumers in general, they may

15. This figure is approximately the same proportion of opt-outs indicated by a review of a large sample of credit-reporting agency files at approximately the same time. For more information on that study, refer to Board of Governors, Report to the Congress on Further Restrictions on Unsolicited Written Offers of Credit and Insurance, pp. 17-27.

16. Durkin, "Credit Cards: Use and Consumer Attitudes," pp. 628-30 and pp. 632-33; and Durkin, "Consumers and Credit Disclosures," pp. 204-6. 
8. Distribution of responses of cardholders and noncardholders regarding opt-out law and government prohibition of credit card solicitations, 2004 Percent

\begin{tabular}{|c|c|c|c|}
\hline $\begin{array}{l}\text { Attitude toward } \\
\text { government intervention }\end{array}$ & Cardholders & Noncardholders & All \\
\hline Response by group & 77.0 & 23.0 & 100.0 \\
\hline $\begin{array}{l}\text { Federal opt-out law } \\
\text { Good idea .......... }\end{array}$ & 82.1 & 74.4 & 80.1 \\
\hline Bad idea ............ & 16.7 & 20.6 & 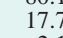 \\
\hline Do not know & $\begin{array}{r}1.3 \\
100 .\end{array}$ & $\begin{array}{r}4.9 \\
1000\end{array}$ & 2.1 \\
\hline Total $\ldots \ldots \ldots$ & 100.0 & 100.0 & 100.0 \\
\hline $\begin{array}{l}\text { Government should } \\
\text { prohibit solicitations }\end{array}$ & & & \\
\hline Yes ................ & $\begin{array}{l}26.9 \\
708\end{array}$ & 49.1 & 31.8 \\
\hline $\begin{array}{l}\text { No } \ldots \ldots \ldots \\
\text { Do not know } \ldots \ldots \ldots \ldots\end{array}$ & $\begin{array}{r}70.8 \\
2.3\end{array}$ & $\begin{array}{r}49.1 \\
1.9\end{array}$ & 2.1 \\
\hline Total $\ldots \ldots \ldots \ldots \ldots$ & 100.0 & 100.0 & 100.0 \\
\hline
\end{tabular}

NotE: Components may not sum to totals because of rounding. Source: Surveys of Consumers, May 2004.

feel that opting out is unnecessary.

The May 2004 survey also found evidence of the "other guy effect." When asked directly whether they think that pre-approved offers of credit cards cause other people, in general, to use too much credit, about 85 percent said yes. When asked alternatively whether pre-approved offers have led them to use too much credit, only 15 percent agreed. But most respondents also did not want the government to take specific actions to rectify the difficulty with excessive credit use that they perceived others might be facing. After questions about voluntarily placing their name on an opt-out list, all respondents (cardholders and noncardholders) were asked for their views on the opt-out law and on government intervention regarding prescreened solicitations. ${ }^{17}$

Their responses to these questions exhibit a distinct preference for an opt-out law, even if most do not personally employ it, and for no government intervention in their opt-out decisions. About 80 percent said that a federal opt-out law is a good idea; the proportion was somewhat higher among cardholders than noncardholders (table 8). But almost two-thirds said they prefer that the government not prohibit prescreened solicitations, even though a majority said they do not open and peruse the ones they receive. Again, this proportion is higher for cardholders than noncardholders (70 percent versus 49 percent).

These findings suggest that the inconvenience associated with receiving the mailings is overall not too great for consumers, even though many apparently

17. Specifically, the first question was "Do you think it is a good idea or a bad idea that there is a federal law that permits you to put your name on a list and then credit card companies cannot send you these offers?" This question was followed immediately by a related question: "Do you think the government should prohibit credit card companies from sending pre-approved offers for credit cards?" consider the mailings junk. Although cardholders are most likely to receive prescreened solicitations for credit cards and are more likely than noncardholders to say that an opt-out list is a good idea, they largely believe that the government should not prohibit such solicitations. Presumably, this feeling is associated with the view that information about new products, features, and pricing is worthwhile-even if it is used only occasionally. Most consumers prefer the availability of an opt-out list, and they also prefer to be the one to choose whether or not to place their names on the list.

In sum, most consumers receive written offers of credit, and a significant portion appear to be at least somewhat familiar with the contents of the mailings, including a minority who were aware of the opt-out law. Among the more than 40 percent of respondents who said that the information in credit card solicitations is helpful, a large majority cited the pricing information as helpful. Only a relatively small proportion had actually acted on the opt-out information and had their names placed on the opt-out list maintained by credit-reporting agencies, popularly known as credit bureaus. Only a small percentage of consumers (15 percent) acknowledged that pre-approved offers of credit cards had led them to overuse credit, but a large majority of consumers (85 percent) believed the solicitations caused other consumers to overuse credit. Nonetheless, the majority of respondents indicated they did not want the government to restrict prescreened solicitations, presumably because they did not want to restrict their own opportunities to receive future offers, even if they mostly responded by disposing of them.

\section{PRIVACY NOTICES AND DISCLOSURES}

Also in May 2004, consumers were surveyed about their knowledge, attitudes, and behavior regarding the privacy policies of their financial institutions. The survey was designed to obtain a benchmark indication of consumers' responses to these notices and a basis for comparison should the format of such notices change measurably in the future.

As might be expected, consumers responded overwhelmingly that privacy policies were important to them, but they gave various reasons why. They indicated that they did not often use privacy notices for direct comparisons between policies of institutions. This latter finding is not surprising, given the receipt frequency of these notices and their sometimes dense appearance.

Survey results indicated that consumers are generally aware of privacy policies at financial institutions, 
9. Responses regarding privacy notices of financial institutions, 2004

Percent

\begin{tabular}{|c|c|c|c|c|}
\hline \multirow{2}{*}{ Question } & \multicolumn{3}{|c|}{ Response } & \multirow{2}{*}{ Total } \\
\hline & Yes & No & $\begin{array}{l}\text { Do Not } \\
\text { Know }\end{array}$ & \\
\hline $\begin{array}{l}\text { Awareness of federal privacy law } \\
\text { for financial institutions ..... }\end{array}$ & 73 & 27 & $*$ & 100 \\
\hline $\begin{array}{l}\text { Receipt of privacy notices from } \\
\text { financial institutions } \ldots \ldots \ldots\end{array}$ & 78 & 22 & $*$ & 100 \\
\hline $\begin{array}{l}\text { Knowledge that main depository } \\
\text { institution has an opt-out policy } \\
\text { All respondents } \ldots \ldots \ldots \ldots . . . . .\end{array}$ & 67 & 7 & 26 & 100 \\
\hline $\begin{array}{l}\text { Those recalling receipt of privacy } \\
\text { notices } \ldots \ldots \ldots \ldots \ldots \ldots \ldots\end{array}$ & 76 & 5 & 19 & 100 \\
\hline
\end{tabular}

* Less than 0.5 percent.

Source: Surveys of Consumers, May 2004

a finding that is not surprising because those with accounts at financial institutions have received them, possibly many. About three consumers in four were aware of a federal law in this area and had received privacy notices from their financial institutions (table 9). About two in three recalled that their main depository financial institution has an opt-out policy concerning information sharing with other companies. Among those in this group who recalled receiving notices, this proportion was three in four. While the response may well contain many guesses, it does indicate that the awareness that such a law exists is widespread.

Concerning attitudes toward financial privacy and privacy policies, consumers appear to regard the privacy policies of financial institutions as generally important to them (table 10). A large majority of users of financial institutions regard the protection of privacy as very important, and they generally believe that their own institutions protect their privacy well. A somewhat smaller proportion of consumers replied that the privacy policy is a key criterion for choosing financial institutions.

Among those respondents who recalled receiving privacy notices from financial institutions, 24 percent thought that privacy notices were "very useful" (second panel of table 10), and 21 percent reported that they were "very confident" that they understood the policies. When asked in a follow-up question why they thought that the statements were useful or not, two-thirds of those who said the notices were useful gave various reasons, but the responses were grouped around a smaller number of themes (data not in table). About 12 percent cited specific features or uses of the notices: explaining rights, enabling them to opt out, or helping them evaluate institutions. Another 16 percent were more vague, noting how the information kept them up to date or provided useful general information or details. Another 30 percent mentioned consumer protections, such as prevention from information misuse by the institution or from identity theft. About one-quarter mentioned general customer awareness, peace of mind, and usefulness for any future problems. About 4 percent said they did not know why they felt the notices were useful; the other 10 percent gave other various answers. Among those who reported the notices were not useful, the majority gave reasons such as too much information, inundation, junk mail, and unhappiness with "legalese."

Concerning behavior with respect to privacy notices received, most consumers who recalled receiving them reported that they generally open and at least glance at them (table 11). Only about 14 percent reported that they threw away the notices without consulting them or filed them for possible later use. Most of those who threw away the notices without even glancing at them did so because they felt the notices were pretty much the same or because they just did not have time or interest in them (data not in table).

Those who at least open and glance at the notices were asked whether they found any particular information important. About 3 percent declined to answer the question, and another 4 percent said they did not

10. Attitudes regarding privacy notices of financial institutions, 2004

Percent

\begin{tabular}{|c|c|c|c|c|c|c|}
\hline Topic & Very & Somewhat & Not very & Not at all & Do not know & Total \\
\hline $\begin{array}{l}\text { Importance that primary financial institution protects } \\
\text { personal information about accounts } \ldots \ldots \ldots \ldots \text {. }\end{array}$ & 88 & 9 & 2 & * & $*$ & 100 \\
\hline $\begin{array}{l}\text { Likelihood of transferring institutions if primary } \\
\text { institution did not protect personal financial }\end{array}$ & & & & & & \\
\hline 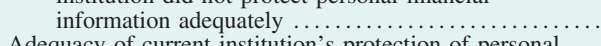 & 70 & 17 & 6 & 6 & 1 & 100 \\
\hline $\begin{array}{l}\text { Adequacy of current institution's protection of personal } \\
\text { financial information } \ldots \ldots \ldots \ldots \ldots \ldots \ldots \ldots \ldots\end{array}$ & 60 & 32 & 2 & 1 & 5 & 100 \\
\hline $\begin{array}{l}\text { Importance of institution's privacy policy compared } \\
\text { with other reasons for choosing financial institutions }\end{array}$ & 48 & 36 & 12 & 3 & 1 & 100 \\
\hline $\begin{array}{l}\text { Among respondents who recalled receiving privacy notices } \\
\text { Usefulness of privacy notices } \\
\text { Confidence in understanding privacy policies }\end{array}$ & $\begin{array}{l}24 \\
21\end{array}$ & $\begin{array}{l}43 \\
52\end{array}$ & $\begin{array}{l}19 \\
20\end{array}$ & $\begin{array}{r}14 \\
6\end{array}$ & $\begin{array}{l}1 \\
1\end{array}$ & 100 \\
\hline
\end{tabular}

NotE: Components may not add to totals because of rounding.

* Less than 0.5 percent.

SOURCE: Surveys of Consumers, May 2004 
11. Behavior response to receipt of privacy notices and to question regarding use of privacy notices to compare institutions, 2004

Percent

\begin{tabular}{|c|c|}
\hline Behavior & Response \\
\hline Open and look carefully at notices & 29.0 \\
\hline Open and glance at notices $\ldots \ldots \ldots \ldots \ldots \ldots \ldots \ldots$ & 57.0 \\
\hline 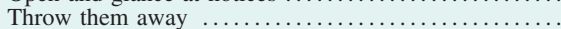 & 10.0 \\
\hline Other (file for later reference) & 4.0 \\
\hline Do not know .................. & $*$ \\
\hline Total $\ldots \ldots \ldots \ldots \ldots \ldots \ldots$ & 100.0 \\
\hline Privacy notices used to make comparisons & \\
\hline 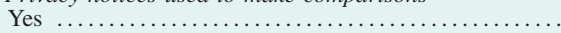 & 5.0 \\
\hline 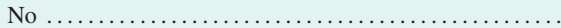 & 95.0 \\
\hline Total $\ldots \ldots \ldots \ldots \ldots$ & 100.0 \\
\hline
\end{tabular}

* Less than 0.5 percent.

Source: Surveys of Consumers, May 2004

know. A majority (57 percent) said no information was particularly important, and the rest offered a variety of answers that mostly focused simply on knowing that the institution would limit access to personal information.

Only about one consumer in twenty reported using the notice to make specific comparisons among institutions, however (second panel of table 11). Furthermore, less than 10 percent who said they had not used the notices for comparisons said they planned to do so in the future (data not in table). Because most consumers are generally satisfied with the privacy policies of their current institutions as they understand them, infrequent use for comparisons is not inconsistent with stated importance of privacy policies. If more consumers were concerned about the policies of their own institutions, presumably more of them would use the notices to seek replacement institutions. The findings indicate that consumers do not review closely the notices they receive, but that lack of attention does not stem from a perception of their inability to understand them.

Finally, the survey asked respondents the meanings of the terms affiliate and opt out, which are sometimes used in privacy notices or in discussions about financial privacy. What was evident from the responses to these questions was that consumers assign various meanings to these two terms, especially to the term affiliate. Slightly more than 40 percent thought the term meant a formal relationship through some sort of joint ownership (table 12). One possibility is that they acquired this meaning by examining privacy notices, but general knowledge and experience is also a likely source. Educational level is also associated with correctly defining the term. Slightly more than onethird of respondents with a high-school education or less attached the meaning of a joint or combined ownership relationship to affiliate, but more than half of college graduates did so. In contrast, more than
12. Accuracy of definitions of selected terms in privacy notices and confidence levels in understanding privacy notices by level of education, 2004

Percent

\begin{tabular}{|c|c|}
\hline Affiliate term: Definition and confidence level & Response \\
\hline Definition referring to aspects of joint ownership ${ }^{1}$ & 43.4 \\
\hline By education level & \\
\hline High-school education or less . & 34.3 \\
\hline Some college ............... & 38.4 \\
\hline College graduate or more $\ldots \ldots \ldots \ldots \ldots \ldots \ldots \ldots$ & 50.7 \\
\hline By confidence level in understanding privacy notices & \\
\hline Very confident & 55.2 \\
\hline Somewhat confident & 40.5 \\
\hline Not very confident . & 39.1 \\
\hline 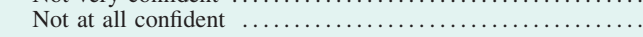 & 31.8 \\
\hline Definition referring to other sorts of formalized relationships ${ }^{2}$ & 18.7 \\
\hline By education level & \\
\hline High-school education or less & 12.4 \\
\hline Some college .............. & 23.6 \\
\hline College graduate or more $\ldots \ldots \ldots \ldots \ldots \ldots \ldots \ldots \ldots$ & 20.4 \\
\hline By confidence level in understanding privacy notices & \\
\hline Very confident & 15.3 \\
\hline Somewhat confident .... & 19.0 \\
\hline Not very confident ... & 21.1 \\
\hline Not at all confident $\ldots . . . .$. & 23.9 \\
\hline Definition referring to other sorts of organizations ${ }^{3}$ & 27.7 \\
\hline By education level & \\
\hline High-school education or less ... & 34.6 \\
\hline 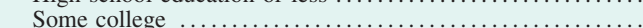 & 33.0 \\
\hline College graduate or more...$\ldots \ldots \ldots \ldots \ldots \ldots \ldots$ & 21.3 \\
\hline By confidence level in understanding privacy notices & \\
\hline Very confident & 17.9 \\
\hline Somewhat confident & 30.6 \\
\hline Not very confident .............. & 29.9 \\
\hline Not at all confident & 34.1 \\
\hline Do not know or no answer & 10.2 \\
\hline By education level & \\
\hline High-school education or less .... & 18.8 \\
\hline Some college .................... & 5.0 \\
\hline 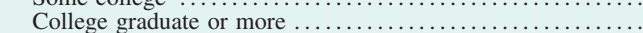 & 7.6 \\
\hline By confidence level in understanding of privacy policies & \\
\hline Very confident & 11.6 \\
\hline Somewhat confident $\ldots \ldots \ldots \ldots \ldots \ldots \ldots \ldots \ldots \ldots \ldots$ & 10.0 \\
\hline Not very confident .... & 9.9 \\
\hline Not at all confident $\ldots . . .$. & 10.2 \\
\hline
\end{tabular}

one-third of those with only a high-school education or less gave generalized answers that did not fit common definitions of affiliate, but only 21 percent of college graduates did so. "Do not know" responses were much more common among those with less than a high-school education.

Little relation existed between answers to the question about the meaning of affiliate and responses to the question about the usefulness of privacy notices. Cross-tabulation of the affiliate definition with the response on notice usefulness showed little variation among groups of consumers (data not in table). Cross-tabulation of correct definition of the term affiliate with confidence in understanding the notices (last line of table 10) revealed a correlation, one slightly higher than the one from the cross-tabulation of the term and response on usefulness. But the correlation was not as strong as the one between correct definition and education level. Thus, understanding of the terminology, at least at the time of the interview, was more dependent on educational level 
12.-Continued

\begin{tabular}{|c|c|}
\hline Opt out term: Definition and confidence level & Response \\
\hline Definition referring to requesting no sharing of information 4 & 75.2 \\
\hline By education level & \\
\hline High-school education or less & 62.7 \\
\hline Some college...$\ldots \ldots \ldots \ldots$ & 74.8 \\
\hline College graduate or more .... & 82.7 \\
\hline Other definitions 5 & 12.6 \\
\hline By education level & \\
\hline High-school education or less ... & 12.6 \\
\hline Some college ................... & 11.6 \\
\hline College graduate or more .......... & 13.2 \\
\hline Do not know or no answer & 12.1 \\
\hline By education level & \\
\hline High-school education or less $\ldots \ldots \ldots \ldots$ & 24.6 \\
\hline Some college $\ldots \ldots \ldots \ldots \ldots \ldots$ & 13.5 \\
\hline College graduate or more ......... & 4.1 \\
\hline
\end{tabular}

Note: Affiliate means any company that controls, is controlled by, or is under common control with another company. Opt out means a direction by the consumer that you not disclose nonpublic personal information about that consumer to a nonaffiliated third party other than as permitted. Definitions come from the Board of Governors of the Federal Reserve System (2000), "Regulation P: Privacy of Consumer Financial Information," Federal Reserve Regulatory Service, 6-2253 and 6-2300 respectively (November).

1. Examples are employees; people within the company; their own banking group; part of their family of companies; parts of their company; companies in the corporation; another entity owned by the parent company; in their network; same ownership; same corporation; branches; satellite banks; joint ventures; sister banks; brother banks; parent company; holding company; subsidiaries; companies they might own; off-shoot companies; organizations connected with, related to, involved with, under the umbrella of the bank; and institutions affiliated to or working with the bank to offer services (for example, loan department, mortgage company, credit card companies owned by the bank, insurance company, and subcontractors)

2. Examples are people, companies, organizations, banks, institutions they work with or deal with, "anybody they do business with," investment companies, stockbrokers, stock markets, and reciprocal market agreements.

3. Examples are other banks, credit unions, lending institutions, other institutions, someone in their industry, counterparts, credit card companies, outside vendors, third-party companies, other organizations, other companies, other businesses, competitors, marketers, companies or businesses they would give or sell your information to, people they sell their lists to, institutions they swap loans with, government agencies, any business of their choosing, and "whoever they want."

4. Examples were requests in writing that the institution not disclose information to affiliates, choice to participate, option to participate or not, and do not want them to share information with affiliates.

5. Examples were have them not disclose financial standing, get on "do not call" list, get on or off a list (not further specified), they could offer selected information for release, you can get out of giving them information, choose not be part of that affiliation, and be left out or dropped.

Source: Surveys of Consumers, May 2004.

than on specific attitudes expressed toward experiences with the notices.

Concerning the meaning of opt out in the context of privacy notices, about three-quarters of respondents answered correctly that the term meant a request that information about them not be shared. As with affiliate, correctness of the response also varied by education.
It is not possible to determine from the answers the respondents gave whether their understanding of opt out was influenced in some way by the privacy notices they had received. Nonetheless, reasonable understanding of the meaning of the term seems fairly widespread at the time of the interview. Here again, the correlation with education was greater than with specific measures of attitudes toward usefulness of the notices. In future studies, another measurement may discover whether privacy notices and general usage of the term among the public, including its use in other areas like credit card solicitations, has had a long-term effect on understanding of the term.

\section{CONCLUSION}

Surveys of consumers regarding their knowledge of, attitudes toward, and use of various required disclosures about consumer financial services indicate that many consumers are aware of the disclosures, have generally favorable attitudes toward them, and often use them for the purposes envisioned by their original sponsors. That is not to say that the responses were not diverse, however; the responses probably always will be as long as individuals have diverse backgrounds, educations, experiences, and needs. Consumers who use their cards to generate credit tend to review more frequently the disclosures of credit costs than those who mainly use their cards as convenient payment devices. This pattern also appears to hold true for the disclosures in credit card solicitations. Those using the cards as credit-generating devices are more likely to review information on annual percentage rates than those using cards primarily to make payments. Consumers also indicate that institutional privacy policies are important to them, but they tend not to examine the notices they receive closely for the most part. Those with more education are more likely to understand the terms affiliate and opt out in the context of a privacy notice. Overall, the survey responses suggest that the disclosures contribute to the informed use of credit by consumers and enhance the competitiveness of consumer credit markets, as envisioned by the sponsors of the disclosure laws. 